ро н лізов но водний режим б сейнової системи олтви: історію гідрологічних досліджень, п р метри гідрологічного режиму, тенденції зміни гідрологічної ситу ції у другій половині XX т поч тку XXI ст., т кож природні умови 6 сейну річки т нтропогенні чинники, які вплив ють н формув ння її водного режиму.

лючові слов : водний режим, гідрологічний пост, стік води, рівень води.

ічк олтв є лівою притокою хідного угу - в жливої тр нскордонної водної ртерії, як протік є по території трьох держ в ( кр іни, ілорусі т ольщі). лизько $80 \%$ г г льного обсягу стічних вод, що їх скид ють у 6 сейн хідного угу н території кр їни різні водокористув чі, ст новлять води міст ьвов , які н дходять у б сейн р. олтв . н чн ч стк (до $35 \%$ ) стічних вод є 3 брудненою [3]. ому кту льне пит ння оцінки екологічного ст ну б сейнової геосистеми олтви для визн чення ії екологічної стійкості, зд тності виконув ти середовищерегулюв льну т ресурсозбережну функції [10]. жливою скл довою н лізу екологічного ст ну річки є дослідження іiї водного режиму.

ст нніми десятиріччями з'явил ся зн чн кількість публік цій результ тів н укових досліджень, присвячених оцінці якості вод 6 сейну хідного угу, проблем м орг ніз ції т функціонув нню гідроекологічного моніторингу [2-4, 7]. н ліз т систем тиз ція н укових пр ць щодо дослідження гідрологічних спектів б сейну р. хідний уг ( . йзенберг (1969), . ишневський (1972), . розд т . исенко (1972), оменко т . олошин (1976), . ов льчук, . ург невич, . ихнович (2002), . ишневський т . осовець (2003), . бокрицьк, . ільчевський, . нченко (2006) т ін.) з свідчили, що недост тню ув гу н уковці приділяють вивченню умов формув ння т чинників впливу н водний режим р. олтви - другої з величиною (після p. т ) лівої притоки р. хідний уг (у меж $\mathrm{x}$ ьвівської обл.).

ш мет - дослідження стоку, рівнів води р. олтви т н ліз природних і нтропогенних чинників, які вплив ють н формув ння їі водного режиму.

одним режимом н зив ють з кономірні зміни в ч сі стоку, швидкостей течії, рівнів води т похилів водної поверхні [5]. одний режим річки з лежить від сукупності фізико-геогр фічних чинників, серед яких в жливу роль відігр ють клім тичні (х р ктер циркуляції тмосфери, режим темпер тури і вологості, кількість т інтенсивність тмосферних оп дів, вип ровув ння) т чинники поверхні водозбору (геологічн будов , рельєф, фізичні т водні вл стивості грунтів, гідрогеологічні умови, рослинний покрив, н явність озер, боліт тощо).

() ург невич ., іпк ., 2012 
ічк олтв (площ $б$ сейну $-1440 \mathrm{kм}^{2}$, довжин - 60 км) бере поч ток в околицях міст ьвов , м є 55 приток, з яких лише сім довжиною пон д 10 км (потоки умний, ричівський, имковецький, річки ерегноївк, ілк, ологірк т дві без н зви) [11]. сновн ч стин 6 сейну р. олтв $є$ в меж х розчленов ної п смової кумулятивноденуд ційної височини лого олісся - смове обужжя. итоки річок б сейну розміщені в меж х одільської височини - озточчя, ьвівське пл то, ологоро- ременецьке п смо. бсолютні висоти ст новлять 250-300 м, похил водотоків - від 1 до 2 м/Км - лівобережжя олтви, т пон д 2 м/км - пр вобережжя. оловний водотік (p. олтв ) н був є четвертого р нгу. ля б сейну х р ктерні сильні зміни структури річкових систем [9]. омінують ре ли збільшення протягом XX ст. (н $0,5-2,0$ км/км²) густоти гідромережі. ерев ж ють звивистий (середня і нижня ч стин р. олтв , нижня ч стин річок ологірк , ерегноївк ) т нтропогенно змінений тип русл . ісцями (р. ілк , потік умний) русло н лежить до к тегорії прямолінійних нерозг лужених. видкість течії сяг є 0,2-0,3 м/с, ширин русл р. олтв 6-12 м, її приток - до 5 м.

одний режим р. олтв поч ли вивч ти н прикінці XIX ст. ерший водомірний пост н олтві відкрили 887 р. поч тку ст. відбулося розширення мережі гідрологічних досліджень [1]. ьогодні н території б сейну р. олтви діє лише один гідрологічний пост (р. олтв - м. уськ) (т бл. 1).

блиця 1

ідрологічні пости н річк х 6 сейну р. олтви

\begin{tabular}{|l|l|c|c|cc|}
\hline \multirow{2}{*}{ одний об’єкт } & \multirow{2}{*}{ ост } & \multicolumn{2}{|c|}{ еріод функціонув ння } & \multirow{2}{*}{ лежність пост } \\
\cline { 3 - 4 } & & відкрито & ліквідов но & \multicolumn{2}{|c|}{} \\
\hline олтв & с. олтв & 1940,1948 & 12.08 .1970 & кр їнське & $*$ \\
\hline олтв & м. уськ & 1887 & діє & кр їнське & $*$ \\
\hline ологірк & смт р сне & 1910 & 1928 & кр їнське & $*$ \\
\hline
\end{tabular}

* пр вління ідрометеорологічної служби кр їни.

ост розт шов но поблизу міського п рку, н лівому березі, н 8 м вище $з$ лізобетонного мосту, поблизу пивз воду, з 7 км від з лізничної ст нції р сне. рилегл до долини річки місцевість - сл бкохвиляст , розчленов н долин ми м лих приток і яр ми, її використовують під сільськогоспод рські угіддя. олин річки поблизу пост i нижче до с мого гирл коритоподібн . хили її висотою 4-6 м, місцями стрімкі, сл бкорозчленов ні, скл дені суглинк ми, тер сов ні. изьку з пл ву з топлює вод 3 рівня 220 см, другу - дещо вищу і ширшу, - 3 рівня 300 см. пл в вище пост двостороння, шириною 250-300 м, симетричн , поросл кущ ми. усло прямолінійне, мулисте, н середині піщ не. ереги висотою до 1,5 м, стрімкі, місцями урвисті, скл дені суглинк ми. гідропості проводять спостереження з рівнем води, темпер турою води, товщиною льоду і льодовими явищ ми, витр т ми т хімічним скл дом води [2].

ивчення особливостей водного режиму р. олтв грунтується н результ т х гідрологічних спостережень у системі ерж вної гідрометеорологічної служби кр їни 3 період 1946-2010 pp.

тік води - в жливий елемент водного режиму. о головних х $\mathrm{p}$ ктеристик стоку води н леж ть витр т води, об'єм стоку, ш р стоку, модуль стоку, коефіцієнт стоку. ередня витр т води р. олтв ст новить $9 \mathrm{~m}^{3} / \mathrm{c}$ і м є тенденцію до зрост ння. ксим льне зн чення з фіксов но у 1980 р. $-17,8$ м³/с, мінім льне - 1950 р. $-3,5$ м 3 с (т бл. 2). 
ідрологічні х р ктеристики р. олтв

\begin{tabular}{|c|c|c|c|}
\hline $\begin{array}{c}\text { ідрологічні } \\
\text { х р ктеристики }\end{array}$ & ередні & ксим льні & інім льні \\
\hline итр т води, $\mathrm{m}^{3} / \mathrm{c}$ & 9,0 & 17,8 & 3,5 \\
\hline одуль стоку, л/с км ${ }^{2}$ & 6,2 & 12,4 & 2,4 \\
\hline р стоку, мм & 391,0 & 194,4 & 77,0 \\
\hline б'єм стоку, $\mathrm{Kм}^{3}$ & 0,294 & 0,563 & 0,111 \\
\hline
\end{tabular}

йбільш б г товодними були роки 1974, 1980 і 1998. йменші витр ти води спостеріг ли у 1946, 1950 і 1951 pp. (рис. 1).

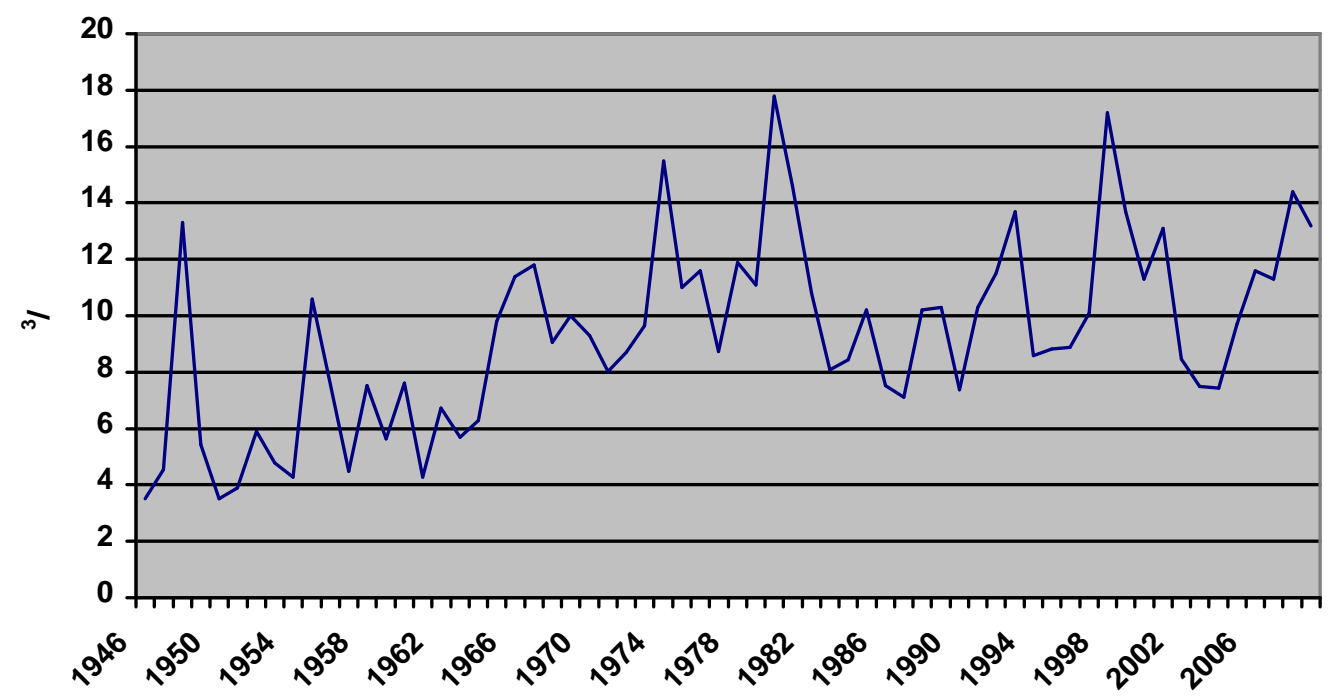

ис. 1. г торічн дин мік стоку води ур. олтв (гп. уськ).

г торічні колив ння водності річки зумовлені колив ннями клім тичних п р метрів. оефіцієнт кореляції між об'ємом стоку і кількістю оп дів ст новить 0,75 [8]. ільш ч стин оп дів вип д є у весняно-літній період (рис. 2).

нутрішньорічні колив ння водності річки зумовлені сезонними змін ми скл дових водного б л нсу річкового б сейну.

внутрішньорічному водному режимі p. олтв $з$ фіксов но з кономірне чергув ння періодів підвищеної т низької водності, які відобр ж ють зміни умов живлення річки (рис. 3,4$)$.

ля річки олтв , зокрем , у роки з м лою з безпеченістю х р ктерні яскр во виp жен веснян повінь, низькі літньо-осіння т зимов межені, яким вл стиві стійкість, м ловодність і зн чн трив лість. нколи межень порушують дощові і т ло-дощові П водки, ун слідок чого ч стк стоку в ці періоди зн чно зрост є, особливо, у роки високої з безпеченості. ередні терміни поч тку весняної повені прип д ють н третю дек ду лютого-першу дек ду березня. ост нніми рок ми, з огляду н потепління клім ту, ці терміни н ст ють р ніше. 


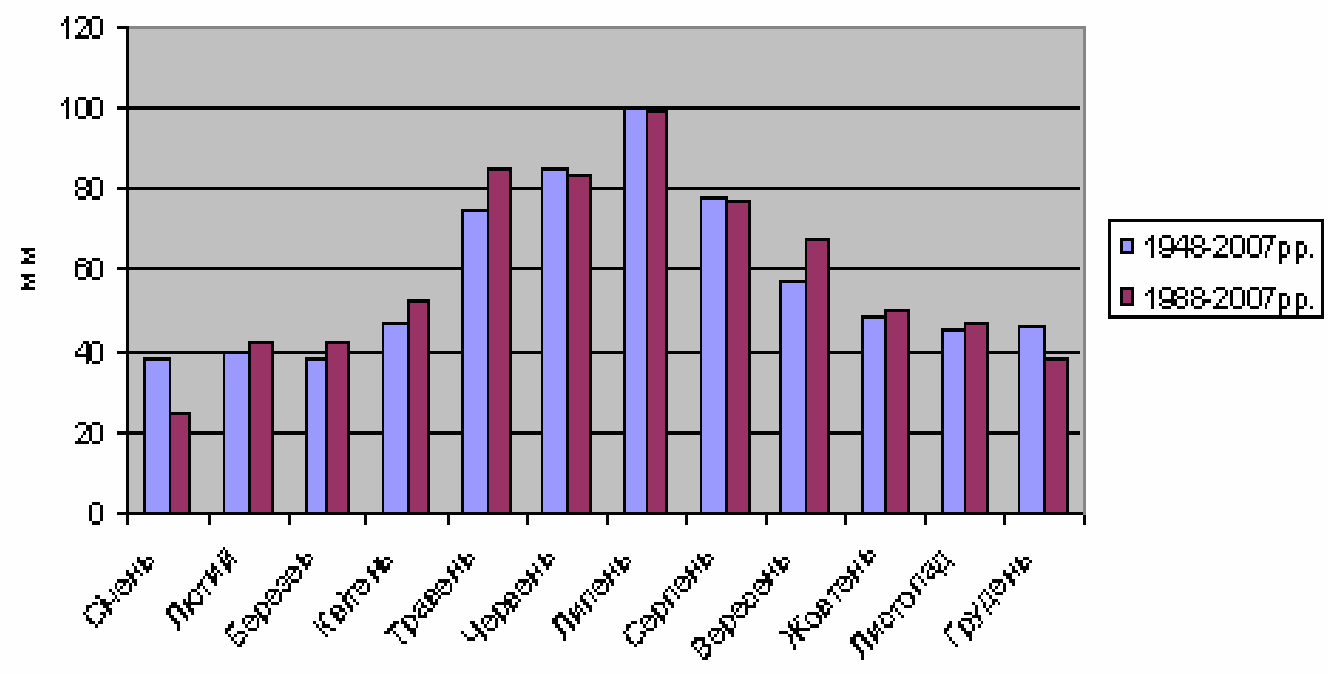

ис. 2. ередньомісячн кількість оп дів з період 1948-2007 pp. т 1988-2007 pp. для ьвів.

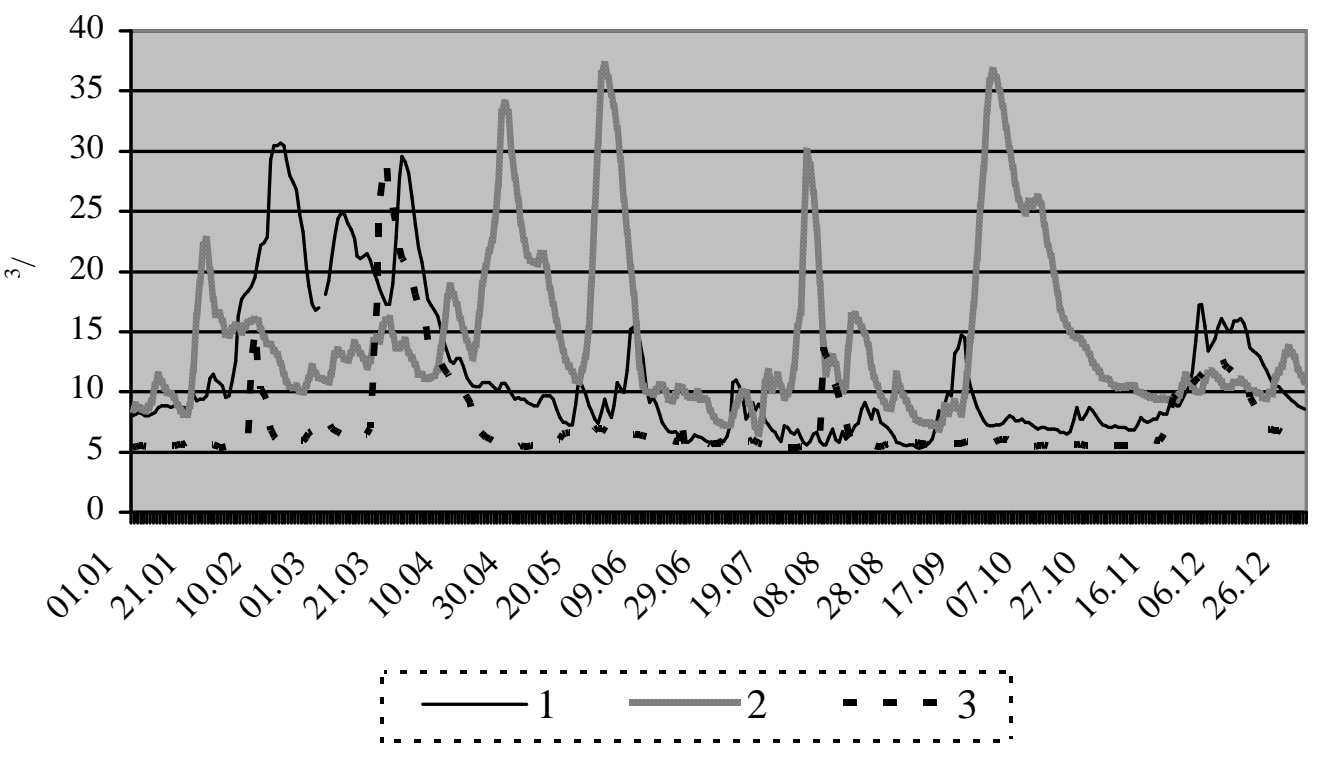

ис. 3. нутрішньорічний розподіл стоку води р. олтв (гп. уськ) у роки різної водності: 1 - середній $з$ водністю (2007); 2 - б г товодний (2008); 3 - м ловодний (2004). 


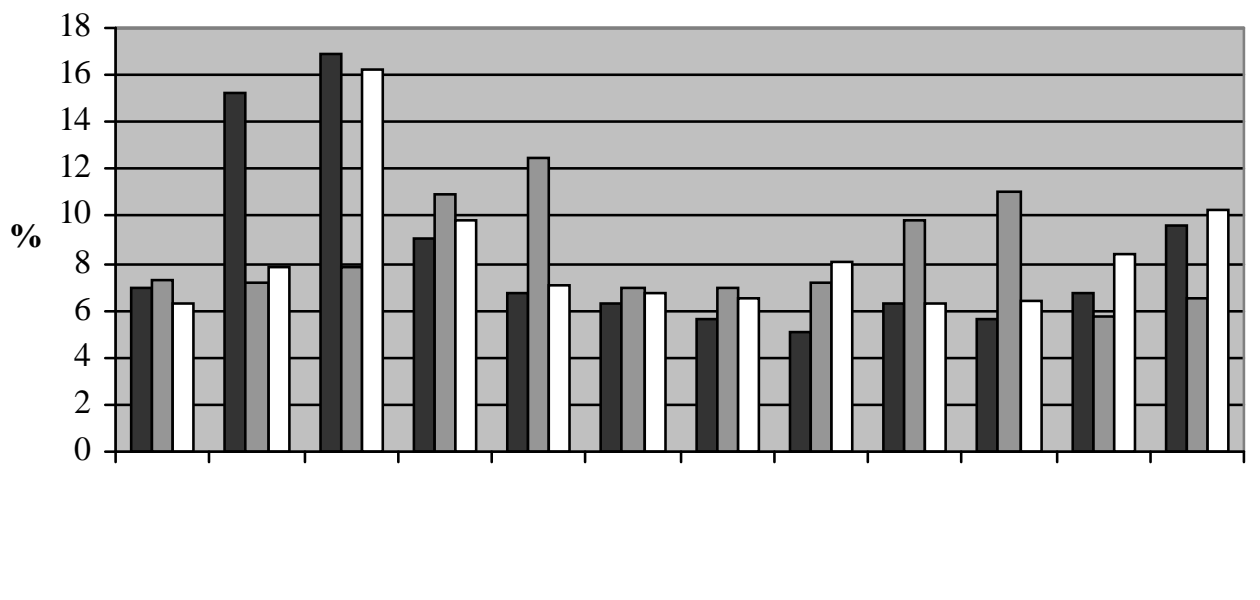

$\square 1 \square 2 \square 3$

ис. 4. ісячн ч стк стоку води p. олтв (гп. уськ) у роки різної водності: 1 - середній 3 водністю (2007); 2 - 6 г товодний (2008); 3 - м ловодний (2004).

періоди повеней т п водків вод ч сто з топлює низьку, іноді й високу з пл ву (рис. 5).

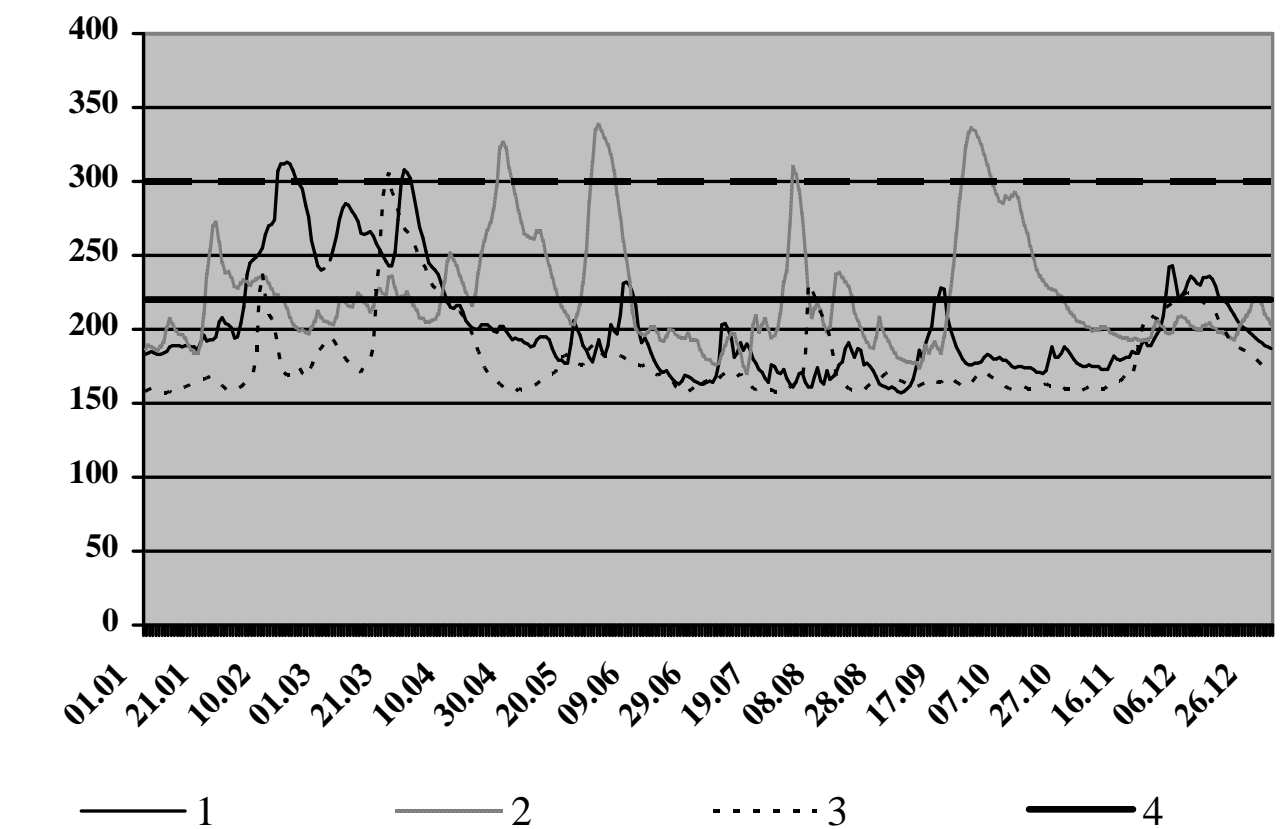

ис. 5. івні води н р. олтв (гп. уськ) у роки різної водності: 1 - середній $з$ водністю (2007); 2 - б г товодний (2008); 3 - м ловодний (2004); 4 - рівень низької з пл ви; 5 - рівень високої з пл ви. 
ормув ння стоку води - б г тоф кторний процес. ля р. олтв х р ктерний вз ємопов'яз ний т вз ємозумовлений вплив н стік води як природних, т к i нтропогенних чинників. йбільше зн чення для формув ння стоку р. олтв м є скид к н ліз ційних вод м. ьвов . ічний обсяг скиду стічних вод т кий, тис. км ${ }^{3}$ : ьвівводок н л $-17,910^{4}$, у ологірку зі ст нції $\mathrm{p}$ сне $-24,1$, у умницю зі ст нції с дівництв с. еслухів - 11,0 (т бл. 3).

блиця 3

бір, скид т безповоротне використ ння води в 6 сейні p. олтв , млн м ${ }^{3 *}$

\begin{tabular}{|c|c|c|c|c|c|c|c|c|c|}
\hline \multirow[t]{3}{*}{$\begin{array}{l}\text { рирод- } \\
\text { ний } \\
\text { об'єкт }\end{array}$} & \multicolumn{4}{|c|}{$\begin{array}{c}\text { бр но води із } \\
\text { природних водних об'єктів }\end{array}$} & \multicolumn{2}{|c|}{$\begin{array}{c}\text { кинуто води в } \\
\text { природні водні } \\
\text { об'єкти }\end{array}$} & \multirow{3}{*}{$\begin{array}{l}\text { ико- } \\
\text { рис- } \\
\text { т но } \\
\text { води }\end{array}$} & \multicolumn{2}{|c|}{$\begin{array}{r}\text { езповоротне } \\
\text { використ ння }\end{array}$} \\
\hline & \multirow{2}{*}{$\begin{array}{l}0 \\
\dot{0} \\
\stackrel{0}{0} \\
\stackrel{2}{1}\end{array}$} & \multicolumn{2}{|c|}{ 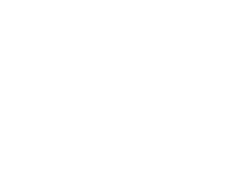 } & \multirow{2}{*}{ 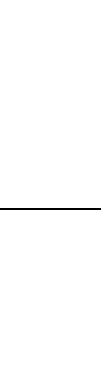 } & \multirow{2}{*}{$\begin{array}{l}0 \\
0 \\
0 \\
0 \\
0 \\
0\end{array}$} & \multirow{2}{*}{ 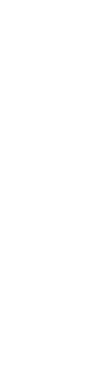 } & & \multirow{2}{*}{ 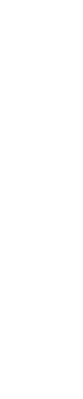 } & \multirow{2}{*}{ 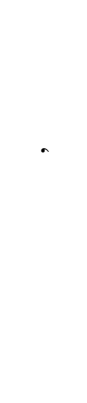 } \\
\hline & & $\begin{array}{l}0 \\
0 \\
0 \\
0 \\
\end{array}$ & 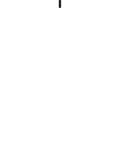 & & & & & & \\
\hline олтв & 7,056 & 2,245 & 0,450 & 4,811 & 161,2 & 0,450 & 5,847 & 60,60 & 154,1 \\
\hline ологірк & 1,350 & 1,350 & 0,450 & - & 0,900 & 0,450 & 0,900 & 0,450 & 0,450 \\
\hline ричівк & 2,495 & 0,878 & - & 1,617 & 0,693 & - & 1,736 & 1,019 & 1,803 \\
\hline ілк & 0,644 & 0,017 & - & 0,627 & 0,024 & - & 0,644 & 0,020 & 0,620 \\
\hline руньк & - & - & - & - & 0,021 & - & - & - & 0,021 \\
\hline
\end{tabular}

тері ли ьвівського обл сного виробничого упр вління водного господ рств .

н чний вплив н гідрологічний режим р. олтв м ють осушув льні меліор ції. території б сейну р. олтви діє дев'ять меліор тивних систем (т бл. 4).

еліор тивні системи в б сейні р. олтв [6]

\begin{tabular}{|c|c|c|c|c|}
\hline $\begin{array}{c}\text { сушув льн } \\
\text { систем }\end{array}$ & $\begin{array}{c}\text { сушув н } \\
\text { площ , г }\end{array}$ & $\begin{array}{c}\text { крит } \\
\text { осушув льн } \\
\text { мереж, км }\end{array}$ & $\begin{array}{c}\text { ідкрит } \\
\text { осушув льн } \\
\text { мереж, км }\end{array}$ & $\begin{array}{c}\text { оки } \\
\text { будівництв і } \\
\text { реконструкції }\end{array}$ \\
\hline олтвинськ & 12154 & 6637,7 & 538,3 & $1936 / 58 / 80 / 87$ \\
\hline умненськ & 3896 & 1837,3 & 317,2 & $1957 / 61$ \\
\hline ологірськ & 7453 & 4611,5 & 255,4 & $1959 / 72 / 89$ \\
\hline ричівськ & 7339 & 3253,9 & 387,0 & 1966 \\
\hline едільнич нськ & 1767 & 656,5 & 86,8 & $1961 / 86$ \\
\hline ілківськ & 8906 & 4823,6 & 389,5 & $1960 / 88$ \\
\hline уровицьк & 5254 & 3119,6 & 291,6 & $1972 / 79$ \\
\hline хторівськ & 2947 & 1897,7 & 133 & 1972 \\
\hline линянськ & 2505 & 1559,9 & 76,8 & 1958 \\
\hline
\end{tabular}


рост ння кількості н селення міст ьвов спричиняє збільшення об'ємів скидів стічних вод у річку, ун слідок чого водний режим водотоку постійно змінюється. ля підтримки н лежного екологічного ст ну річки першочерговим з вд нням є визн чення допустимих норм господ рського н в нт ження т потенці лу с моочищення водотоку. ивчення гідрологічного режиму річки олтв - в жливої скл дової екологічних досліджень - кту льним з вд нням сьогодення.

1. йзенберг . . бщ я х р ктеристик гидрогр фической сети / . . йзенберг // есурсы поверхностных вод . . . . идрометеоизд т, 1969. - . .6, ып. 1. - .118-138.

2. кологічний моніторинг регіону: експертн оцінк ст ну і функціонув ння / з ред. д-р геогр.

н ук, проф. . ов льчук / [ . ов льчук, . олошин, . ихнович, . ишневський т ін.]. ьвів : пілля, 2009. -608 с.

3. бокрицьк . . ідроекологічний ст н б сейну хідного угу н території кр їни / . . бокрицьк , . . і ільчевський, . . нченко. - . : ік - ентр, 2006. -184c.

4. бокрицьк . . т н моніторингу якості поверхневих вод у б сейні p. хідний уг / . . бокрицьк // ідрологія, гідрохімія і гідроекологія. - 2002. - . 3. - . 161-166.

5. г льн гідрологія : підручник / . . ільчевський, . . бодовський, . . ребінь т ін. $\therefore$ иївський університет, 2008. - 399 с.

6. сторія водного господ рств т меліор ції земель ьвівської обл сті / . . ільчишин, . . оз к, . . озловський. - ьвів : ьвівський облводгосп, 2009. - 32 с.

7. ов льчук . . ідроекологічний ст н поверхневих вод річкових систем верхньої ч стини б сейну хідного угу / . . ов льчук, . . ург невич // ідрологія, гідрохімія і гідроекологія. $-2003 .-$. 5. - .240-248.

8. ов льчук . . ідрологічний н ліз б сейнової системи хідного угу / . . ов льчук, . . ург невич, . . ихнович // ідрологія, гідрохімія і гідроекологія. - 2002. - . 4. - . 89-100. 9. ург невич . . колого-геоморфологічний н ліз б сейну хідного угу : втореф. дис. ... к нд. геогр ф. н ук: 11.00 .07 / . . ург невич; ьвівський н ціон льний університет імені в н р нК . - ьвів : 2001. -22 с.

10. ург невич . . етодичні підходи до н лізу екологічного ст ну річкового 6 сейну олтви / . . ург невич, . . іпк // еогр фічні з с ди вирішення регіон льних проблем. м'янець- одільський, 2010. - . 124-126.

11. inк . . колого-геогр фічн х р ктеристик річкової системи олтви / . . іпк // т н і перспективи розвитку конструктивної геогр фії. - ьвів : імені в н р нк, 2010..111-118. 


\section{CONDITIONS OF FORMING AND FACTORS OF WATER REGIME OF THE POLTVA RIVER}

\section{Kurhanevych, M. Shipka}

Ivan Franko National University of Lviv, . Doroshenko St., 41, UA - 79000 Lviv, Ukraine

The analysis of water regime of the Poltva River system has been carried out. History of hydrological investigations, hydrological regime parameters, trends of the long-term changes of hydrological regime in XX-XXI centuries have been characterized. Natural conditions and man-made factors of the river water regime forming have been analyzed.

Key words: water regime, hydrological post, water discharge, water level.

$$
\text { • ург невич, . ипк }
$$

ьвовский н иион льный университет имени в н р нко,

$$
\text { ул. . орошенко, 41, г. ьвов, 79000, кр ин }
$$

ро н лизиров но водный режим б ссейновой системы олтв : историю гидрологических исследов ний, п р метры гидрологического режим, тенденции изменения гидрологической ситу ции во второй половине и в н ч ле вв., т кже природные условия б ссейн реки и нтропогенные ф кторы, которые влияют н формиров ние ее гидрологического режим .

лючевые слов : водный режим, гидрологический пост, сток воды, уровень воды. 